\title{
Competitiveness levels in cattle herd farms
}

\author{
Competitividade em propriedades com criação de bovinos
}

\author{
Pedro Rocha Marques ${ }^{I^{*}}$ Júlio Otávio Jardim Barcellos $^{\mathrm{I}}$ Matheus Dhein Dill ${ }^{\mathrm{I}}$ \\ Eduardo Antunes Dias ${ }^{\mathrm{I}}$ Eduardo Vaz Torres Azevedo ${ }^{\mathrm{I}}$ Vinícius do Nascimento Lampert ${ }^{\mathrm{II}}$ \\ Concepta Margaret McManus ${ }^{\text {III }}$
}

\begin{abstract}
The aim of this experiment was to identify improvement demands for farms with different levels of competitiveness in the west of Rio Grande do Sul state, Brazil. A total of 63 owners of large farms were interviewed (farms with an area greater than 900ha) by applying a semi-structured questionnaire, guided by four drivers: technology (TEC), management (MAN), market relations (MR) and the institutional environment (IE).It was used the Statistical Analysis System 9.2 software to perform the cluster analysis and identify farmers' characteristics. Three random clusters with different levels of competitiveness were observed: low competitiveness level (LCL), middle competitiveness level (MCL) and high competitiveness level (HCL). The 29 variables (sub factors) were evaluated in the cluster analysis according to level of impact on competitiveness, being classified into variables of high, medium or low impact. Stratification was carried out, ranking demands for improvements from aspects attributed by experts in relation to sub factors. The farmers with low competitiveness level (LTL) had an unfavorable status for MAN, while the farmers belonging to clusters MCL and HCL have, respectively, favorable and neutral status for the same driver. The management characteristics determined the level of competitiveness of the farms surveyed.
\end{abstract}

Key words: cluster, level of impact, management, ranking, stratification.

\section{RESUMO}

$O$ objetivo deste experimento é a identificação das demandas de melhorias para fazendas com diferentes níveis de competitividade no Oeste do RS. Entrevistaram-se 63 produtores grandes (área $=+900$ ha) por meio de um questionário semiestruturado, dividido em quatro direcionadores: tecnologia (TEC), gestão (MAN), relações de mercado (MR) e ambiente institucional (IE). Utilizou-se o software SAS 2002, versão 9.0, para realização da análise de cluster, realizando a tipologia dos produtores. Nesta análise, formaram-se aleatoriamente três clusters, sendo denominados de baixo nível de competitividade ( $L C L)$, médio nível de competitividade (MCL) e alto nivel de competitividade (HCL). Dividiram-se as 29 variáveis (subfatores) avaliadas na análise de cluster de acordo com nivel de impacto na competitividade das fazendas de bovinos de corte, sendo classificadas em variáveis de alto, médio ou baixo impacto. Esta estratificação do ranking de demanda de melhorias foi realizada a partir dos pesos atribuidos pelos especialistas aos subfatores. Os pecuaristas com baixo nível de competitividade apresentaram status desfavorável para MAN, enquanto os pecuaristas pertencentes aos clusters MCL e HCL apresentaram, respectivamente, status neutro e favorável para o mesmo direcionador. Portanto, a gestão é determinante para definir o nível de competitividade das fazendas entrevistadas.

Palavras-chave: cluster, estratificação, nivel de impacto, gestão, ranking.

\section{INTRODUCTION}

Beef cattle production in Brazil has grown exponentially in recent decades, mainly through advancing agricultural frontiers and technology use (WILKINSON, 2010). Rio Grande Sul (RS) state, on the other hand, has been losing markets compared with states from Northern and Central-West regions of the country. Therefore it is important to evaluate the factors which contribute to this loss, especially in the western region of the Rio Grande do Sul state which has the largest effective herd size with $3,329,943$ heads in 2009 (SIDRA/IBGE, 2010). This

IDepartamento de Zootecnia, Universidade Federal do Rio Grande do Sul (UFRGS), Avenida Bento Gonçalves, 7712, 91540-000, Porto

Alegre, RS, Brasil. E-mail: rochamarques@hotmail.com.*Corresponding author

"Embrapa Pecuária Sul, Bagé, RS, Brasil.

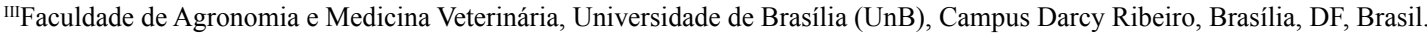
Received 03.17.14 Approved 06.24.14 Returned by the author 10.21.14 CR-2014-0401.R1 
region shows a highly heterogeneous type of cattle farming, especially with respect to technology use and managerial practices. The regular production systems use only the natural grassland occupied by high animal stock per area without any pasture or financial management and no technology adoption. Indeed, while farmers with a low level of competitiveness should invest in pasture management to reach medium level, medium level farmers should invest in production system management. In addition, farmers with high level of competitiveness should invest in management practices to improve the system (MARQUES et al., 2011). The introduction of new technologies should, therefore, respect the following assumptions: that there is knowledge on the impact on production within the production system, the amplitude of the result (everything right $\mathrm{x}$ everything wrong), assess whether the cost of using technology is a limiting factor for all other operational activities on farm; existence of positive cash flow and resources to use the technology, as well as market situation (OAIGEN et al., 2009). The objective of the present paper was to identify the demand for improvement on farms with different characteristics in the western region of Rio Grande do Sul state, Brazil, a lowland area that holds perennial grasses and herbs with a Cfa climatic classification (BERLATO \& FONTANA, 1999).

\section{MATERIAL AND METHODS}

This study was carried out in the western region of Rio Grande do Sul State in 2010 with farmers from 8 municipalities (Alegrete, Santana do Livramento, São Gabriel, Rosário do Sul, Uruguaiana, Quaraí, Itaqui and São Borja). The sampling was based in the large production scale and cattle herd operations control (high market influence) covering $90.16 \%$ of the cattle herd of this region. The mean farm area was $3,737.79$ ha, which is above 15 physical modules according to the classification of the Land Statute created in 1964 (intentional non-probabilistic sample). A questionnaire was applied to 63 farmers and eight specialists were interviewed. Six types of agricultural activity were found on these farms (cattle \& sheep; cattle, sheep \& horses; crops, cattle, sheep \& horses; crops, cattle \& horses; crops \& cattle; crops, cattle \& sheep). Cattle production integrated with rice production was the predominant system $(n=23)$ followed by crops plus cattle and sheep production $(n=18)$. High levels of integration with crop production $(82.5 \%)$ and sheep farming $(60.3 \%)$ on these farms should be noted (MARQUES et al, 2011).
These also aided in the identification of key points for structuring and testing the questionnaire for the farmers. Between 5 and 10 farmers were interviewed per municipality, with these being interviewed within a two day period within the municipality. Considering the study objectives, their range and period of execution, a rapid assessment or quick appraisal study was used. DUNN (1994) states that it is a qualitative method which uses secondary data sources with non-probabilistic and semi structured samples with key-agents in the production chain. To evaluate patterns it was used previous studies as a support for profiles competitiveness of regional farmers (ANDREATTA, 2009; AGUINAGA, 2009). For the profiles evaluation on the sector, the status of a production system was determined by different factors. Each element was first classified as controllable, almost controllable or not controllable by experts who helped in the development of the questionnaire. These factors, classified as drivers, were grouped into four blocks: technology (TEC), management (MAN), market relations (MR) and institutional environment (IE). The drivers were then divided into sub factors which were identified and analyzed regarding the intensity of contribution to the competitiveness of the sector (favorably or unfavorably). Information collected from interviews with experts and preliminary literature research was used to attribute a score to each factor (Table 1). The sub factors of each vector summed 1.00. The score for each vector was defined by the level of influence that the farmer had over it. The vectors which a farmer had greater ability to modify had higher weights. These weights were established by the technical committee composed of eight specialists randomly and arbitrarily chosen by considering the importance of the sub factor for competitiveness in the beef cattle production system (Table 1). Seven of them were academics and one a businessman, all having experience in the cattle market. Drivers were divided in sub factors which were identified in the semistructured questionnaire (quick appraisal method) and analyzed according to the type of answer given by the farmer (favorably or unfavorably) regarding the competitiveness of its farm system and received a weight as described above. After the interviews with farmers each sub factor was classified from Highly Unfavorable (HU) to Highly Favorable (HF). There were four questions per sub factor and answers were positive or negative. The criteria used to qualify the answer and determine the percentage of acceptance (PA) was HF - highly favorable: 04 (four) positive answers (100\%); F - favorable: 03 (three) positive 
Table 1 - Variables (vectors and sub factors) with their respective weights.

\begin{tabular}{|c|c|}
\hline Variable & Weight \\
\hline Technology (TEC) & 3.50 \\
\hline Type of production system (TYP) & 0.10 \\
\hline $\begin{array}{l}\text { Pasture quality, management and grass species } \\
\text { (PAST) }\end{array}$ & 0.15 \\
\hline Animal supplementation (SUP) & 0.15 \\
\hline Integration crops and animal production (ICAP) & 0.10 \\
\hline Reproductive management (REP) & 0.10 \\
\hline Herd genetics (GEN) & 0.05 \\
\hline Herd health $(\mathrm{HH})$ & 0.15 \\
\hline Production indices control (PIC) & 0.05 \\
\hline Regular technical assistance (RTA) & 0.10 \\
\hline Routine management of animals (ROT) & 0.05 \\
\hline Management (MAN) & 3.50 \\
\hline Workforce training (WT) & 0.15 \\
\hline Patrimonial (PAT) & 0.05 \\
\hline Finance and cash flow (FCF) & 0.10 \\
\hline Strategic planning (EP) & 0.05 \\
\hline Control of production costs (CPC) & 0.15 \\
\hline Calculate financial indicators (CFI) & 0.10 \\
\hline Herd identification (HI) & 0.10 \\
\hline Commercialization (COM) & 0.10 \\
\hline Use of Information Technology on-farm (IT) & 0.05 \\
\hline Scale of production (SP) & 0.15 \\
\hline Market Relationships (MR) & 2.00 \\
\hline Relationship farmer-supplier (RFS) & 0.35 \\
\hline Relationship farmer - abattoir (RFA) & 0.35 \\
\hline Formation of prices (FP) & 0.15 \\
\hline Product differentiation (PD) & 0.15 \\
\hline Institutional Environment (IE) & 1.00 \\
\hline Access to technological innovations (ATI) & 0.15 \\
\hline Tax and workforce policies (TWP) & 0.15 \\
\hline Environmental policies and fiscalization (EPF) & 0.15 \\
\hline Agricultural credit policies (ACP) & 0.10 \\
\hline Health policies and fiscalization (HPF) & 0.15 \\
\hline Official legislation and farm ownership (OLFO) & 0.10 \\
\hline Farmer organization (FO) & 0.20 \\
\hline
\end{tabular}

answers (75\%); $\mathrm{N}$ - neutral: 02 (two) positive answers (50\%); U - unfavorable: 01 (one) positive answer (25\%); HU - highly unfavorable: no positive answers $(0 \%)$. A competitiveness index (CI) was created from the scores for each sub factor. This was composed of scores and weights (values) between competitiveness vectors and sub factors. The vectors technology, management, market relations and institutional environment were evaluated. The sub factor values (SV) were obtained from the answers from the farmers, using the percentage of accuracy (PA) of each reply and weight (WS) as in equation 1 : $\mathrm{SV}=\mathrm{PA} \times \mathrm{WS}$
The Vector value (VV) was obtained from the sum of values for sub factors and vector weights (VW).

$$
V V=\frac{\sum_{n=1}^{n} N F_{n}}{\sum_{n=1}^{n} P F_{n}} x V W
$$

The competitiveness index (CI) was obtained by summing the values for the vectors

$$
\begin{aligned}
& \mathrm{CI}=\mathrm{NV}_{\text {technology }}+\mathrm{NV}_{\text {Management }}+\mathrm{NV}_{\text {Market relations }}+ \\
& \mathrm{NV} \\
& \text { Institutional Environment }
\end{aligned}
$$

The final classification was defined using predefined criteria: Highly unfavourable (0$0.2)$; Unfavourable (0.21-0.4); Neutral (0.41-0.6); Favourable (0.61-0.8); Highly Favourable (0.81-1.0). Statistical Analyses were carried out using $\mathrm{SAS}^{\circledR}$. The original variables with less than $10 \%$ or greater than $90 \%$ positive replies were removed as these were not discriminatory. Therefore, out of the 71 variables, only 29 were analyzed. A multiple correspondence analysis was carried out (MCA) to identify the relationship between farmers and variables (drivers and sub factors). A cluster analysis was carried out with individual information from farmers using Ward's method and Quadratic Euclidean Distance. Three clusters were formed and defined as competitiveness levels: low (LCL), medium (MCL) and high (HCL). In this context it was defined the competitiveness level as the degree of technology adopted by the farmer, the degree of management used to control the farm finances and the relationships strength between each farm and the market players (slaughter house, supermarkets and other farmers). The mean value for each of the 29 sub factors was used to rank the competitiveness levels per cluster. A stratification of the ranking for demands for improvements was carried out using the weights given by specialists for the sub factors, classifying them into three groups depending on the impact on the competitiveness level within the production system (low, medium, high).

\section{RESULTS AND DISCUSSION}

Farmers in this region of Brazil show a high level of technology use. The famers use technologies without intensive use of management practices. This can be seen as the vector MAN had lower scores than TEC. MR and IE were classified as neutral for competitiveness of farms in the region (MARQUES et al., 2011). All three clusters showed favorable results for the driver TEC (Table 2), although farmers in HCL showed greater control over this factor 
compared to those in LCL and MCL, expressed by the Highly Favourable (HF) status. High performance farms demand innovation (ALLEN et al., 2007) while farmers with low performance system still need to control their costs better as well as calculate financial indicators for their farm (GASPAR et al., 2009; HOLMANN et al., 2008). Farmers with a low competitiveness level (LCL) had an unfavorable status for MAN while farmers in clusters MCL and HCL had neutral and favorable status respectively. Farm management is important in determining levels of competitiveness in beef cattle herds as the driver MAN in each cluster corresponds to the level of farm performance. Farmers who do not manage adequately their farm tend to be less competitive and show difficulty to sustain the business over the years (HOLMANN et al., 2008; ROSADO \& LOBATO, 2009). The only unfavorable factor for LCL was the MR variable, differing from MCL and HCL. With an increase in levels of competitiveness in the production systems, market relations like farmerabattoir may improve farms performance as they become less conflicting. When negotiations between the parts are frequent, the level of trust between those agents increases (MONDELLI \& ZYLBERSZTAJN, 2008 ), leading to an environment of confidence and reciprocity (VIEIRA et al., 2009). The organization of farmers is the main sub factor which needs to be implemented for the institutional environment become favorable (for LCL and MCL) or highly favorable (HTL). The organization of farmers is fundamental for the negotiation with large abattoirs (BRAGA, 2010), for the diffusion of technologies and organization of open days. The analysis of demands with high impact (Table 3) shows that farmer organization (FO) and relationship between farmer and abattoir (RFA) are those that need to be improved in all three clusters. The first three subfactors for TEC and MAN to be corrected for LCL are cost control (CPC), pasture

Table 2 - Performance of three Clusters expressed by status shown for different competitiveness drivers.

\begin{tabular}{lcccc}
\hline CLUSTERS & TEC $^{(4)}$ & MAN $^{(5)}$ & MR $^{(6)}$ & IE $^{(7)}$ \\
\hline LCL $^{(1)}$ & $\mathrm{F}^{(10)}$ & $\mathrm{U}^{(8)}$ & $\mathrm{N}^{(9)}$ & $\mathrm{N}^{(9)}$ \\
MCL $^{(2)}$ & $\mathrm{F}^{(10)}$ & $\mathrm{N}^{(9)}$ & $\mathrm{F}^{(10)}$ & $\mathrm{N}^{(9)}$ \\
$\mathrm{HCL}^{(3)}$ & $\mathrm{HF}^{(11)}$ & $\mathrm{F}^{(10)}$ & $\mathrm{F}^{(10)}$ & $\mathrm{F}^{(10)}$ \\
\hline
\end{tabular}

${ }^{(1)}$ LTL: Low competitiveness level. ${ }^{(2)}$ MTL: Medium competitiveness level. ${ }^{(3)} \mathrm{HTL}$ : High competitiveness level. ${ }^{(4)}$ TEC: Technology. ${ }^{(5)}$ MAN: Management. ${ }^{(6)}$ MR: Market . ${ }^{(7)}$ IE: Institutional environment. ${ }^{(8)} \mathrm{U}$ : Unfavorable. ${ }^{(9)} \mathrm{N}$ : Neutral. ${ }^{(10)} \mathrm{F}$ : Favorable. ${ }^{(11)} \mathrm{HF}$ : Highly favorable.
Table 3 - Ranking of demand for improvements per cluster with high impact sub factors for competitiveness on-farm by order of priority.

\begin{tabular}{llll}
\hline Order & LCL & $\mathrm{MCL}$ & $\mathrm{HCL}$ \\
\hline 1 & $\mathrm{FO}^{(1)}$ & $\mathrm{FO}^{(1)}$ & $\mathrm{FO}^{(1)}$ \\
2 & $\mathrm{RFA}^{(2)}$ & $\mathrm{CPC}^{(3)}$ & $\mathrm{RFA}^{(2)}$ \\
3 & $\mathrm{CPC}^{(3)}$ & $\mathrm{RFA}^{(2)}$ & $\mathrm{PAST}^{(4)}$ \\
4 & $\mathrm{PAST}^{(4)}$ & $\mathrm{HRT}^{(5)}$ & $\mathrm{HRT}^{(5)}$ \\
5 & $\mathrm{HRT}^{(5)}$ & $\mathrm{SP}^{(6)}$ & $\mathrm{SP}^{(6)}$ \\
6 & $\mathrm{SP}^{(6)}$ & $\mathrm{PAST}^{(4)}$ & $\mathrm{CPC}^{(3)}$ \\
7 & $\mathrm{SUP}^{(7)}$ & $\mathrm{SUP}^{(7)}$ & $\mathrm{SUP}^{(7)}$ \\
8 & $\mathrm{RFS}^{(8)}$ & $\mathrm{RFS}^{(8)}$ & $\mathrm{RFS}^{(8)}$ \\
\hline
\end{tabular}

${ }^{(1)}$ F.O:Farmer organization. ${ }^{(2)}$ RFA: Relationship Farmer Abattoir. ${ }^{(3)} \mathrm{CPC}$ :Control of production costs. ${ }^{(4)} \mathrm{PAST}$ :Pasture quality management and grass species. ${ }^{(5)} \mathrm{HRT}$ : Workforce training. ${ }^{(6)} \mathrm{SP}$ :Scale of production. ${ }^{(7)} \mathrm{SUP}$ :Animal supplementation. ${ }^{(8)} \mathrm{RFS}$ : Relationship farmer-supplier.

management (PAST) and human resource training (HRT). The three sub factors that need to be corrected, in order of importance, are CPC, HRT and SP (MCL) and PAST, HRT and SP (HCL). For HCL farmers cost control is already managed efficiently, as it is not registered as one of the main needs of this group of farmers, justifying the favorable status for this cluster in the MAN driver (Table 2). GHEMAWAT, 2000 , described that the farms that need to become competitive must take actions in costs control and differentiation of the final product. With an increase in the level of competitiveness in beef cattle farms the level of requirements and complexity of activities also increases (PAIM et al., 2003). Some authors (BLACK et al., 1993; PEREIRA et al., 2004) argued that with the intensification of the production system and an increase in the complexity of farm duties, an analysis of the production system should be carried out together with an analysis of the human resources performance. Training is therefore fundamental for excellence in operations as in clusters MCL and HCL.

\section{CONCLUSION}

Only highly competitive farms showed efficient management practices. With an increase in the performance of the farm, the market relations that historically are conflicting (farmer-abattoir) tends to reduce in importance and the institutional environment becomes a more important driver for highly competitiveness farmers (HCL). Farmers with higher competitiveness profiles (HCL and MCL) need innovation while farms with lower competitiveness (LCL) need better management. An increase in competitiveness leads to a better workforce 
qualification because of the raise in complexity of ranch activities.

\section{ACKNOWLEDGEMENTS}

To Coordenação de Aperfeiçoamento de Pessoal de Nível Superior (Capes) for the scholarship granted and assistance.

\section{REFERENCES}

AGUINAGA, A.J.Q. Caracterização de sistemas de produção de bovinos de corte na região da Campanha do estado do Rio Grande do Sul. 2009. 150f. Tese (Doutorado em Zootecnia)Universidade Federal do Rio Grande do Sul, Porto Alegre, RS. Available from: <http://hdl.handle.net/10183/22993?locale=pt BR>. Accessed: jan. 21, 2011

ALLEN, V.G. et al. Integrated irrigated crop-livestock systems in dry climates. Agronomy Journal, v.99, p.346-360, 2007. Available from: <https://www.agronomy.org/publications/aj/ abstracts/99/2/346>. Accessed: apr. 07, 2012. doi:10.2134/ agronj2006.0148.

ANDREATTA, T. . 2009. 241f. Tese (Doutorado em Desenvolvimento Rural) - Universidade Federal do Rio Grande do Sul, Porto Alegre, RS. Available from: <http://hdl.handle. net/10183/16416>. Accessed: apr. 07, 2012.

BERLATO, M.A.; FONTANA, D.C.. Variabilidade interanual da precipitação pluvial e rendimento da soja no Estado do Rio Grande do Sul. Revista Brasileira de Agrometeorologia, v.7, n.1, p. 119 125, 1999.

BLACK, J.L. et al. Role of computer simulation in the applications of knowledge to animal industries. Australian Journal of Agriculture Research, v.44, n.3, p.541-555, 1993. Available from: $<$ http://www.publish.csiro.au/paper/AR9930541.htm>. Accessed: mar. 16, 2012. doi:10.1071/AR9930541.

BRAGA, M.J. Redes, alianças estratégicas e intercooperação: o caso da cadeia produtiva de carne bovina. Revista Brasileira de Zootecnia, v.39, supl esp, p.11-16, 2010. Available from: <http:// dx.doi.org/10.1590/S1516-35982010001300002>. Accessed: may 27, 2012. doi: 10.1590/S1516-35982010001300002.

DUNN, T. Rapid rural appraisal: A description of the methodology and its application in teaching and research at Charles Stuart University, Wagga Wagga Australia. Rural Society, v.4, n.3-4, p.1-11, 1994. Available from: <http://pubs.e-contentmanagement. com/doi/abs/10.5172/rsj.4.3-4.30>. Accessed: apr. 07, 2012.

GASPAR, P. et al. Assessing the technical efficiency of extensive livestock farming systems in Extremadura, Spain. Livestock Science, v.121, n., p.7-14, 2009. Available from: <http://www. sciencedirect.com/science/article/pii/S1871141308001558>. Accessed: may. 13, 2012. doi: 10.1016/j.livsci.2008.05.012.

GHEMAWAT, P. A estratégia e o cenário dos negócios: textos e casos. Porto Alegre: Bookman, 2000. 380p

HOLMANN, F. et al. The beef chain in Costa Rica: identifying critical issues for promoting its modernization, efficiency, and competitiveness. Livestock Research for Rural Development, v.20, article 51, 2008. Available from: <http://www.lrrd.org/ lrrd20/4/holmb20051.htm>. Accessed: jul. 12, 2012.

MARQUES, P.R. et al. Competitiveness of beef farming in Rio Grande do Sul State, Brazil. Agricultural Systems, v.104, p.689-693, 2011. Available from: <http://www.sciencedirect.com/ science/article/pii/S0308521X11001168>. Accessed: sep. 11, 2012. doi: 10.1016/j.agsy.2011.08.002.

MONDELLI, M.; ZYLBERSZTAJN, D. Determinantes dos arranjos contratuais: o caso da transação produtorprocessador de carne bovina no Uruguai. Revista de Economia e Sociologia Rural Brasileira, v.46, n.3, p. 831868, 2008. Available from: <http://dx.doi.org/10.1590/S010320032008000300010>. Accessed: mar. 16, 2012. doi: 10.1590/ S0103-20032008000300010.

OAIGEN, R.P. et al. Análise da sensibilidade da metodologia dos centros de custos mediante a introdução de tecnologias em um sistema de produção de cria. Revista Brasileira de Zootecnia, v.38, p.1155-1162, 2009. Available from: <http://dx.doi. org/10.1590/S1516-35982009000600025>. Accessed: nov. 25, 2011. doi: 10.1590/S1516-35982009000600025.

PAIM, T.C.D. et al. Estratégias de gestão de recursos humanos em empresas de agronegócio do planalto médio do Rio Grande do Sul. Texto para discussão. Passo Fundo: Faculdade de Ciências Econômicas, Administrativas e Contábeis, Universidade de Passo Fundo (UPF), 2003. 14p. Available from: <www.upf.tche.br/ cepeac/download/td 03 2003.pdf>. Accessed: dec. 03, 2010.

PEREIRA, M.A. et al. Gestão de recursos humanos em empresas de bovinos de corte no Triângulo Mineiro. Organizações Rurais e Agroindustriais, v.6, n.2, p.61-74, 2004. Available from: <http:// ageconsearch.umn.edu/bitstream/43684/2/revista_v6_n2_juldez 2004 5.pdf $>$. Accessed: may. 27, 2012.

ROSADO, A.G.J.; LOBATO, J.F.P. Application of a model of management by macroprocesses to a beef cattle enterprise: a case study. Revista Brasileira de Zootecnia, v.38, n.11, p.22802288, 2009. Available from: <http://www.lume.ufrgs.br/bitstream/ handle/10183/97051/000732725.pdf? sequence=1>. Accessed: oct. 09, 2012.

SIDRA/IBGE (SISTEMA DO INSTITUTO BRASILEIRO DE GEOGRAFIA E ESTATÍSTICA DE RECUPERAÇÃO AUTOMÁTICA). Banco de dados agregados. Available from: $<\mathrm{http}: / /$ www.sidra.ibge.gov.br/bda/tabela/protabl.asp? $\mathrm{c}=73 \& \mathrm{z}=\mathrm{t} \& \mathrm{o}=1 \& \mathrm{i}=\mathrm{P}>$. Accessed: nov. 27, 2010

VIEIRA, J.G.V. et al. Um estudo sobre colaboração logística entre indústria de bens de consumo e redes de varejo supermercadista. Gestão \& Produção, v.16, n.4, p.556-570, 2009. Available from: <http://dx.doi.org/10.1590/S0104530X2009000400006>. Accessed: jun. 23, 2012. doi: 10.1590/ S0104-530X2009000400006.

WILKINSON, J. Transformações e perspectivas dos agronegócios brasileiros. Revista Brasileira de Zootecnia, v.39, supl esp, p.26-34, 2010. Available from: <http://dx.doi.org/10.1590/S151635982010001300004>. Accessed: nov. 25, 2011. doi: 10.1590/ S1516-35982010001300004 